\title{
Hak Guna Bangunan Untuk Investasi dalam Bidang Pariwisata
}

\author{
Ida Ayu Putu Larashati ${ }^{1}$
}

${ }^{1}$ Fakultas Hukum Universitas Udayana, E-mail: idaayularashati@gmail.com

Info Artikel
Masuk :31 Januari 2020
Diterima : 2 Februari 2020
Terbit : 30 April 2020
Keywords :
Building Use Rights,
Investment and Land
Conversion
Corresponding Author:
Ida Ayu Putu Larashati, E-
mail:
idaayularashati@gmail.com
DoI :
Hata kunci:
dan Alih Fungsi Lahan
Tand.2020.v05.i01.p17

\begin{abstract}
Abstrak
The role of the National Land Law in development is not yet perfect, but in reality the National Land Law has also succeeded in supporting development activities in all fields in the supply and management or utilization of the required land and legal certainty in its control and management or use. This study aims to examine building rights for investment in tourism. The method used is a normative research method due to legal uncertainty in the regulation of building rights as a form of tourism investment. The development of the tourism industry has an impact on various aspects of people's lives, both from the planned tourism industry and the unplanned implementation of the tourism industry. The impact of the planned implementation of the tourism industry development can be optimally anticipated. The principles of carrying out investments by using building rights as the basis for their rights can help the development of tourism because the holders of land titles do not lose ownership of their land. The structuring of sustainable tourism development is a development that has economic, socio-cultural and environmental dimensions so that it has justice not only for future generations. In this construction, tourism must be seen as a system that includes various components that interact with and influence each other. Therefore, it is needed a synergy of policies governing the implementation of tourism with a multisectoral and multidisciplinary approach to service integration, and the synergy of the government and the community in the use of land with Building Use Rights for tourism purposes.
\end{abstract}

Abstract
Peran Hukum Tanah Nasional dalam pembangunan belum
sepenuhnya sempurna, namun pada kenyataannya Hukum Tanah
Nasional pula telah mampu membantu dalam kegiatan-kegiatan
pemanfaatan atau pengelolaan tanah baik berupa pembangunan
maupun segala bidang yang berkaitan dengan pengelolaan tanah
lainnya, yang diperlukan serta kepastian hukum dalam penguasaan
dan pengelolaan/penggunaannya. Penulisan ini bertujuan untuk
mengkaji hak guna bangunan untuk investasi dalam bidang
pariwisata. metode yang dipergunakan adalah metode penelitian
normatif mengingat adanya ketidakpastian hukum dalam pengaturan
hak guna bangunan sebagai bentuk investasi pariwisata.
Perkembangan industri pariwisata memberikan dampak bagi berbagai
segi kehidupan masyarakat, baik itu dari industri pariwisata yang
direncanakan dan lebih-lebih dari pelaksanaan industri pariwisata
yang tanpa perencanaan. Dampak dari pelaksanaan pembangunan
industri pariwisata yang telah direncanakan dapat seoptimal mungkin
untuk diantisipasi. Prinsip-prinsip penyelenggaraan investasi dengan
menggunakan hak guna bangunan sebagai alas haknya dapat
membantu pengembangan pariwisata karena pemegang hak milik atas
tanah tidak kehilangan kepemilikan atas tanahnya. Ekonomi, social




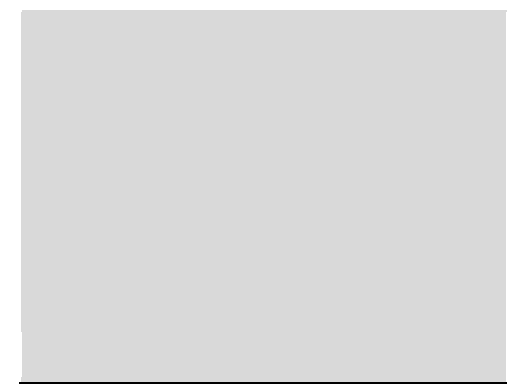

\begin{abstract}
budaya, dan lingkungan hidup merupakan dimensi dari pembangunan pariwisata berkelanjutan. Konstruksi pariwisata harus dinilai sebagai suatu sistem yang meliputi beragam komponen yang saling mempengaruhi saling berinteraksi. Dengan demikian dibutuhkan kebijakan yang mengatur penyelenggaraan pariwisata yang bersinergi dengan pendekatan multisektor dan multidisiplin integrasi pelayanan, dan sinergisitas pemerintah dan masyarakat dalam pemanfaatan tanah dengan Hak Guna Bangunan untuk kepentingan pariwisata
\end{abstract}

\title{
1. Pendahuluan
}

Tanah adalah faktor yang paling utama dalam sejarah peradaban manusia, yang pada awalnya manusia hanya melakukan perburuan dan bersifat nomaden untuk memenuhi kebutuhan hidupnya, berubah menjadi menetap. Bercocok tanam dan menguasai sebagian wilayah tanah sebagai teritorialnya, dari sanalah tanah mempunyai nilai ekonomis dan fungsi sosial dalam kehidupan manusia. Semakin banyak luas tanah yang dimiliki sejalan dengan semakin besarnya status sosial yang dimiliki dalam masyarakat. Tidak hanya itu saja, tanah juga memiliki nilai filosofis yang tidak bisa lepas dari nilai sosial dan kebudayaan, serta memiliki nilai politik. Oleh karena begitu besarnya peranan tanah didalam kehidupan manusia ditambah lagi dengan jumlah ketersediaan akan tanah terbatas, berbanding terbalik dengan populasi manusia yang terus bertambah, bukan hal yang mengherankan lagi apabila tanah aset yang paling istimewa dan berharga yang sarat menimbulkan permasalahan dalam penguasaan pengelolaan maupun pemanfaatan tanah tersebut.

Oleh karena begitu besarnya peranan tanah dalam kehidupan manusia dalam pemenuhan kebutuhan dasarnya maka diperlukan suatu regulasi yang bertujuan untuk mengatur pengelolaan, penggunaan, penguasaan, penyediaan dan pemeliharaan tanah agar terciptanya suatu kepastian hukum dalam hal penguasaan maupun pemanfaatannya sehingga terciptanya perlindungan hukum dan keadilan sosial bagi rakyat, terutama bagi mereka yang mengelola tanah negara seperti contohnya petani, dengan tetap mempertahankan kemanfaatan, kelestarian dan kemampuannya dalam pemanfaatan tanah tersebut.

Peran Hukum Tanah Nasional dalam pembangunan memang belum dapat dilakukan sempurna, namun pada kenyataannya hukum tanah nasional telah mampu membantu dalam kegiatan-kegiatan pemanfaatan atau pengelolaan tanah baik berupa pembangunan, maupun segala bidang yang berkaitan dengan penyediaan pengeloaan dan pemanfaatan tanah yang diperlukan dalam hal kepastian hukum dalam penguasaan maupun dalam pengelolaannya.

Usaha dalam bidang pariwisata merupakan hal yang sangat menjanjikan, dan kegiatan usaha di bidang ini sangat erat kaitannya dengan pengelolaan tanah, salah satu contohnya jasa penyediaan akomodasi atau objek-objek wisata. Penyelenggaraan usaha pariwisata ini telah diatur dalam Undang-Undang No. 10 Tahun 2009 tentang Kepariwisataan, lebih spesifiknya pada pasal 14, dimana dalam pasal tersebut mengandung usaha apa saja yang termasuk dalam kategori usaha di bidang pariwisata, seperti contohnya usaha destinasi kegiatan hiburan dan rekreasi, jasa penyediaan makanan dan minuman, jasa akomodasi, jasa informasi pariwisata, wisata tirta, spa dan lainnya. 
Semakin merambahnya pariwisata diikuti dengan keberadaan penyediaan akomodasi yang menjamur tanpa memperhitungkan daya dukung lingkungan dan memgabaikan dampak negatif dari tindakan pembangunan tersebut seperti contohnya pertumbuhan fisik yang tidak teratur, pelanggaran perijinan dan alih fungsi tanahmenyebabkan permasalahan terhadap pengelolaan peruntukan tanah dimana terjadi alih fungsi tanah dari untuk kepentingan masyarakat banyak beralih untuk kepentingan pemodal besar sehingga alih fungsi lahan dari tanah-tanah pertanian menjadi tanah untuk kepentingan fasilitas pariwisata tidak terelakkan lagi, ribuan hektar tanah pertanian hilang setiap tahunnya.\ Hal tersebut dapat terjadi karena adanya pihak-pihak yang berkepentingan yaitu : pemerintah, swasta dan masyarakat.

Di Indonesia sendiri memiliki Bali sebagai salah satu propinsi yang menjadi tujuan favorit, tidak hanya dari wisatawan dalam negeri, tetapi juga menjadi primadona bagi wisatawan mancanegara. Keindahan alam bali dan kentalnya budaya, adat istiadat yang unik dan sangat beragam menjadi salah satu faktor utama yang menjadi daya tarik wisatawan untuk datang ke Bali. Semakin berkembangnya pariwisata Bali, sektor-sektor pendukung yang memiliki kaitan langsung dengan pariwisata ikut berkembang seperti di bidang perdagangan, hotel, restoran, informasi pariwisata, jasa perjalanan wisata, sektor-sektor lain yang tidak memiliki keterkaitan secara langsung dengan pariwisata seperti sektor keuangan, industri, persewaan dan jasa mampu memberikan kontribusi besar terhadap Pendapatan Asli Daerah (PAD).

Perkembangan industri pariwisata memberikan dampak bagi berbagai segi kehidupan masyarakat, baik itu dari industri pariwisata yang direncanakan dan lebihlebih dari pelaksanaan industri pariwisata yang tanpa perencanaan. Dampak dari pelaksanaan pembangunan industri pariwisata yang telah direncanakan dapat seoptimal mungkin untuk diantisipasi walaupun seringkali hasil yang dicapai tidaklah selalu sesuai dengan harapan. Namun pada kenyataannya perkembangan industri pariwisata yang terjadi seringkali mendahului dari perencanaan atau yang diperkirakan, sehingga dampak negatif yang muncul pun baru dapat diketahui setelah munculnya berbagai permasalahan yang ditimbulkan, sehingga pemanfaatan lahan untuk kepentingan pariwisata sangat penting untuk dikaji. Dalam kegiatan kepariwisataan, salah satu objek investasinya dapat berupa Hak Guna Bangunan (HGB) yang mana HGB tersebut termasuk dalam kategori investasi di bidang pertanahan.Dibutuhkan suatu sinergi kebijakan yang mengatur penyelenggaraan pariwisata dengan pendekatan multisektor dan multidisiplin integrasi pelayanan, dan sinergisitas pemerintah dan masyarakat dalam pemanfaatan tanah dengan Hak Guna Bangunan untuk kepentingan pariwisata.

\section{Metode Penelitian}

Tulisan ini menggunakan metode pendekatan perundang-undangan dan pendekatan konseptual mengingat adanya problem norma pada penyelenggaraan pariwisata dengan memanfaatkan Hak Guna Bangunan sebagai obyek pembangunannya. Sedangkan teknik penelurusan bahan hukum menggunakan teknik studi dokumentasi dan analisis deskriptif.

\section{Hasil Dan Pembahasan}

\subsection{Prinsip Penyelenggaraan Investasi Pariwisata dengan Hak Guna Bangunan}


Investasi merupakan kegiatan bisnis yang dalam pengaturannya termasuk dalam Hukum Bisnis. Menurut Clive Smtthoff sebagaimana yang dikutip dalam Buku Hukum Bisnis Pariwisata, hukum bisnis merupakan bidang hukum yang tercipta dari dan dalam praktek bisnis. Prinsip-prinsipnya terdapat dalam commercial law yang kemudian diterapkan melalui hukum bisnis. ${ }^{1}$ Aspek perijinan adalah aspek yang paling menonjol dalam sistem hukum investasi. Oleh karena, didalam penyelenggaraan investasi mencakup beraneka ragam aspek yang saling berkaitan. Misalnya alokasi dan eksplorasi yang acapkali bersentuhan dengan kedaulatan ekonomi politik dan sosial maka dari itu perizinan memiliki peranan yang sangat penting. Instrumen izin ini digunakan untuk memberikan perlindungan agar kegiatan investasi ini tidak berubah menjadi kegiatan yang bersifat eksploitasi. Dengan demikian kegiatan pelaksanaan investasi harus didasari dan telah memperoleh legalitas baik dari kesepakatan yang timbul karena adanya perjanjian ataupun dari Undang-Undang.Pada prinsipnya dalam melakukan kegiatan investasi izin adalah hal mutlak yang harus dimiliki.

Izin dalam melaksanakan investasi bukan merupakan suatu hal yang dapat diperoleh dengan mudah dan cuma-cuma, dalam pemberian izin tersebut harus didasari dengan penilaian dan pertimbangan. Dalam hukum investasi aspek perizinan mempunyai kewenangan untuk memberikan atau menolak. Dengan demikian sepatutnya hukum investasi memiliki fungsi untuk dapat mengarahkan dan memfasilitasi investasi agar dapat mencapai tujuan-tujuan yang diperuntukkan bagi kesejahteraan masyarakat luas, tidak hanya terpaku pada kewenangan untuk melarang atau memberikan tanpa diikuti dengan peraturan yang jelas.

Kegiatan investasi ini kerap kita temukan dalam bidang pariwisata. Karna tidak dapat dipungkiri usaha di bidang pariwisata ini secara ekonomis sangat menjanjikan dan banyak sektor-sektor ekonomi lainnya yang memiliki kaitan langsung dengan pariwisata ikut berkembang seperti di bidang perdagangan, hotel, restoran, informasi pariwisata, jasa perjalanan wisata, sektor-sektor lain yang tidak memiliki keterkaitan secara langsung dengan pariwisata seperti sektor keuangan, industri, persewaan dan jasa mampu memberikan kontribusi besar terhadap Pendapatan Asli Daerah (PAD). Maka dari itu para investor berbondong-bondong baik dari dalam negeri maupun luar negeri melakukan kegiatan usaha di bidang pariwisata.

Di Indonesia sendiri memiliki hukum kepariwisataan nasional yangpada hakekatnya berlandaskan pada asas Negara Kesejahteraan. Ini dibuktikan dalam isi preambul Undang-Undang Kepariwisataan. Hal ini sesuai dengan teori Negara kesejahteraan yang menegaskan bahwa Negara harus mampu memberikan jaminan bagi kesejahteraan rakyat. dalam Undang-Undang Kepariwisataanini juga terkandung hasrat kepariwisataan dalam mengatur dan mengayomi nilai-nilai budaya tradisional sebagai obyek wisata yang menjadi pionir usaha jasa pariwisata Indonesia, yakni untuk tujuan yang mulia yakni kesejahteraan rakyat. Selain itu dalam Undang-Undang Kepariwisataan mengatur tentang prinsip penyelenggaraan kepariwisataan pada Pasal 5. Adapun prinsip-prinsip kepariwisataan yang terkandung dalam Pasal 5 UndangUndang tentang kepariwisataan adalah "menjunjung tinggi norma agama dan nilai budaya sebagai pengejawantahan dari konsep hidup dalam keseimbangan hubungan antara manusia dan Tuhan Yang Maha Esa, hubungan antara manusia dan sesama manusia, dan hubungan antara manusia dan lingkungan; menjunjung tinggi hak asasi

${ }^{1}$ Wyasa Putra, I.B, dkk, (2010). “Hukum Bisnis Pariwisata, Refika Aditama”, Bandung, hal. 55. 
manusia, keragaman budaya, dan kearifan lokal; memberi manfaat untuk kesejahteraan rakyat, keadilan, kesetaraan, dan proporsionalitas; memelihara kelestarian alam dan lingkungan hidup; memberdayakan masyarakat setempat; menjamin keterpaduan antarsektor, antardaerah, antara pusat dan daerah yang merupakan satu kesatuan sistemik dalam kerangka otonomi daerah, serta keterpaduan antarpemangku kepentingan; mematuhi kode etik kepariwisataan dunia dan kesepakatan internasional dalam bidang pariwisata; dan memperkukuh keutuhan Negara Kesatuan Republik Indonesia".

Dengan adanya prinsip-prinsip penyelenggaran pariwisata ini diharapkan dapat menjadi dasar berprilaku bagi penyelenggara kegiatan pariwisata. agar dapat meminimalisir dampak negatif akibat dari perkembangan di sektor pariwisatayang begitu pesat seperti contohnya pertumbuhan fisik yang tidak teratur, pelanggaran perijinan dan alih fungsi tanahmenyebabkan permasalahan terhadap pengelolaan peruntukan tanah dimana terjadi alih fungsi tanah dari untuk kepentingan masyarakat banyak beralih untuk kepentingan pemodal besar sehingga alih fungsi lahan dari tanah-tanah pertanian menjadi tanah untuk kepentingan fasilitas pariwisata tidak terelakkan lagi, ribuan hektar tanah pertanian hilang setiap tahunnya.

Objek dari investasi yang spesifik menjadi suatu aspek yang tidak dapat diabaikan dan betsifat teknis didalam sistem hukum kepariwisataan. Hal tersebut terkandung dalam peraturan perundang-undangan tentang kepariwisataan. Investasi yang baik harus memiliki tanggung jawab moral dan sosial dalam pelaksanaannya tidak hanya terpaku pada kegiatan yang bertujuan untuk mendapatkan keuntungan atau profit semata. Kendala dalam kegiatan investasi bidang pariwisataberkaitan dengan terbatasnya lahan sebagai ruang investasi pariwisata ini berkembang, tingginya harga tanah, dan dapat berpotensi menggeser penduduk asli digantikan dengan investor-investor luar yang nantinya akan berdampak pada memudarnya kebudayaan asli setempat. Hal ini dapat disiasati dengan jalan pemilik tanah hanya memberikan hak guna bangunan kepada pihak investor, sehinnga tidak kehilangan kepemilikan atas tanahnya.

Ada beberapa regulasi yang berkaitan dengan Hak Guna Bangunan yaitu, Peraturan Pemerintaah Nomor 40 Tahun 1996 tentang Hak Guna Bangunan, Hak Guna Usaha, dan Hak Pakai Atas Tanah dengan Undang-Undang Nomor 5 Tahun 1960 tentang Peraturan Dasar Pokok-Pokok Agraria. ${ }^{2}$ Sri Hajati dalam pengukuhan Guru Besar berpendapat, ada ketidaksesuaian antara yang masing-masing regulasi tersebut yang dapat diuraikan sebagai berikut. Beberapa aspek yang memiliki ketidak singkronan ntara Peraturan Pemerintaah Nomor 40 Tahun 1996 dengan UndangUndang Nomor 5 Tahun 1960 tentang Peraturan Dasar Pokok-Pokok Agraria ; a) Asal Tanah Hak Guna Bangunan, b) Terjadinya Hak Guna Bangunan, dan c) Terjadinya Hak Guna Bangunan³.

a) Asal Tanah Hak Guna Bangunan,

\footnotetext{
3 Pengukuhan Guru Besar, 2005, Restrukturisasi Hak Atas Tanah dalam Rangka Pembaruan Hukum Agraria Nasional, Pidato Pengukuhan Guru Besar dalam Bidang Ilmu Hukum Universitas Airlangga, Surabaya.
} 
Mengenai Asal Tanah Hak Guna bangunan. Dalam Peraturan Pemerintaah Nomor 40 Tahun 1996 mengatur bahwa asal tanah Hak Guna Bangunan adalah tanah negara, tanah Hak Pengelolaan, dan Tanah Hak Milik sedangkan dalam Undang-Undang Pokok Agraria mengatur bahwa asal tanah Hak Guna Bangunan adalah tanah yang dikuasai oleh negara dan tanah Hak Milik saja.

\section{b) Terjadinya Hak Guna Bangunan}

Pada Peraturan Pemerintaah Nomor 40 Tahun 1996 bahwa “Hak Guna Banunan bersal dari tanah negara terjadi dengan keputusan pemberian hak, Hak Guna Bangunan yang berasal dari tanah hak milik terjadi dengan akat pemberian Hak oleh Pejabat Pembuat Akta Tanah (PPAT) dan Hak Guna Bangunan yang berasal dari hak pengelolaan terjadi dengan pemberian hak berdasarkan usul hak pengelolaan, sedangkan dalam Undang-Undang Pokok Agraria mengatur bahwa Hak Guna Bangunan dari Tanah Negara terjadi dengan penetapan pemerintah sedangkan Hak Guna Bangunan yang berasal dari tanah Hak Milik terjadi dengan Perjanjian Otentik".

\section{c) Terjadinya Hak Guna Bangunan}

Berkenaan dengan Jangka Waktu Hak Guna Bangunan. Dalam Peraturan Pemerintaah Nomor 40 Tahun 1996 mengatur bahwa untuk keperntingan penananman modal, kepada pemegang Hak Guna Banunan diberi jangka waktu paling lama 30 tahun, dijamin perpanjangannya unutk jangka waktu paling lama 20 tahun, dan dijaminpembaharuan haknya untuk jangka waktu paling lama 30 tahun, sedangkan dalam Undang-Undang Pokok Agraria mengatur bahwa jangka waktu Hak Guna Bangunan untuk pertama kali paling lama 30 tahun dan dapat diperpanjang untuk jangka waktu paling lama 20 tahun.

Peraturan Pemerintaah Nomor 40 Tahun 1996 jugabelum sepenuhnyamampu menjadi payung hukum dalam mencegah monopoli pengusaan dan penggunaan tanah. Hanya terdapat satu pasal yang mengatur batas minimum dan menetukan luas minimum tanah yang dapat diberikan Hak guna Usaha dalam Peraturan Pemerintaah Nomor 40 Tahun 1996, yaitu 5 hektar dan patas maksimumnya 25 hektar, dalam PP ini tidak diatur dengan tegas mengenai monopoli pengunaan dan penguasaan tanah oleh sekelompok atau oleh golongan tertentu $\mathrm{u}^{4}$.

Terlepas dari hal tersebut, ketentuan mengenai syarat subjek hak guna bangunan telah diatur dalam Undang-Undang No 5 Tahun 1960 tentang Peraturan Dasar Pokok Pokok Agraria tepatnya pada Pasal 36, yang pada intinya memgatur mengenai syarat bagi siapa saja yang dapat mempunyai "hak guna bangunan. Yang dapat memiliki hak guna bangunan ialah warga negara Indonesia, atau badan hukum yang didirikan menurut hukum Indonesia dan berkedudukan di Indonesia". apabila orang atau badan hukum yang mempunyai hak guna bangunan yang tidak memenuhi syarat untuk memperoleh hak guna bangunan dalam jangka waktu 1 (satu) tahun wajib mengalihkan atau melepaskan kepada pihak lain yang memenuhi syarat atas hak guna bangunan. Apabila hak guna bangunan tersebut tidak dialihkan atau

\footnotetext{
${ }^{4}$ Mustofa dan Suratman, 2013, Penggunaan Hak Atas Tanah Untuk Industri, Sinar Grafika, Jakarta, hal. 175.
} 
dilepaskan dalam jangka waktu yang telah di tetapkan, maka hak tersebut telah dinyatakan hapus karena hukum. ${ }^{5}$

Ada tiga jenis terciptanya hak guna bangunan yang didasarkan pada asal tanahnya, yaitu ; a) hak guna bangunan atas tanah Negara, b) hak guna bangunan atas tanah pengelolaan, dan c) hak guna bangunan atas tanah Hak milik. Prosedur terciptanya Hak Guna Bangunan atas tanah Negara ini diatur dalam pasal 32 sampai dengan pasal 48 Peraturan Menteri Agraria/Kepala Badan Pertanahan Negara No.3 tahun 1999, yang telah diubah oleh Pasal 4, Pasal 9, Pasal 14, yang telah diubah oleh pasal 4, pasal 8 dan pasal 11 Peraturan No 1 tahun 2011. Dalam pasal 22 dan 23 Peraturan Pemerintah No.40 tahun 1996, sebagai tanda bukti adanya hak guna bangunan diterbitkan sertipikat, dengan cara hak guna bangunan tersebut didaftarkan oleh pemohon kepada kepala kantor Pertanahan Kabupaten/Kota setempat untuk dicatatkan dalam Buku Tanah.

Sedangkan prosedur terciptanya Hak Guna Bangunan atas tanah pengelolaan diatur dalam Peraturan Menteri Negara Agraria/Kepala Badan Pertanahan Negara No. 9 tahun 1999. Hak guna bangunan atas tanah pengelolaanini terjadi didasarkan atas keputusan pemberian hak atas usul pemegang Hak Pengelolaan, yang diterbitkan oleh Badan Pertanahan Nasional berdasarkan Pasal 4 Peraturan Menteri Negara Agraria/Kepala Badan Pertanahan No. 3 tahun 1999 yang telah diubah dalam pasal 4, pasal 4 dan pasal 11 Peraturan Badan Pertanahan Nasional No. 1 tahun 2011

Hak guna bangunan atas tanah Hak Milik terjadi dengan adanya pemberian hak tersebut oleh pemegang Hak Milik atas tanah dengan akta yang dibuat oleh Pejabat Pembuat Akta Tanah (PPAT). Yanh mana berdasarkan Pasal 24 Peraturan Pemerintah No. 40 tahun 1996 Akta PPAT ini wajib didaftarkan Kepala Kantor Pertanahan Kabupaten/Kota setempat untuk dicatatkan didalam Buku Tanah. Bentuk akta PPAT ini termuat dalam Lampiran Peraturan Menteri Agraria/Kepala Badan Pertanahan Nasional No. 3 tahun 1997. ${ }^{6}$

Untuk kelangsungan pelaksanaan investasi dalam bidang pariwisata Pemanfaatan Hak Guna Bangunan (HGB) sebagaimana diatur dalam UUPA tersebut diatas merupakan landasan dalam kerjasama investasi yang dapat memeberikan manfaat baik bagi investor sebagi penyandang dana maupun bagipemilik lahan. Untuk itu investor dapat mendirikan berbagai usaha dibidang pariwisata dengan betbagai jenis usahanya.

Dalam Peraturan Perundang-Undangan No. 10 Tahun 2009 tentang Kepariwisataan hanya meliputi jenis-jenis usaha dalam bidang usaha pariwisata yang meliputi wisata tirta dan spa, daya tarik wisata, jasa informasi wisata, kawasan pariwisata, jasa makanan dan minuman, konfersi dan pameran, perjalanan insentif, penyediaan akomodasi. Yang mana dalam undang-undang ini tidak menjelaskan secara tegas mengenai pembatasan-pembatasan bidang usaha yang dapat dilakukan dalam kegiatan kepariwisataan

\footnotetext{
${ }^{5}$ Kartini Mulyadi dan Gunawan Widjaja, 2004, Hak-Hak atas Tanah, Kencana Predana Media Group, Jakarta, hal. 190-191.

${ }^{6}$ Urip Santoso, 2012, Hukum Agraria : Kajian Komperhensif, Kencana Prenada Media Group, Jakarta, hal. 110-111.
} 
Dalam Undang-Undang No. 25 tahun 2007 tentang Penanaman Modal lebih khususnya dalam Pasal 14 mengatur mengenai bidang-bidangusaha yang tidak boleh dilaksanakan yaitu seperti ; Produksi senjata mesiu, peralatan perang dan alat peledak, dan bidang usaha yang secara eksplit dinyatakan terutup oleh undang-undang. ${ }^{7}$ Lebih lanjut lagi Pemerintah menetapkan bidang usaha terbuka dengan persyaratan berdasarkan kriteria kepentingan nasional yaitu; pengawasan produksi dan distribusi, koperasi, peningkatan kapasitas teknologi, partisipasi modal dalam negeri serta kerjasama dengan badan usaha yang ditunjuk oleh pemerintah, sebagaimana yang diatur dalam Pasal 12 ayat 5 Undang-Undang No. 25 tahun 2007 tentang Penanaman Modal.

Ketentuan yang lebih mengkhusus lagi dibidang usaha pariwisata justru ditemukan dalam suatu Keputusan Menteri Perhubungan Nomor SK.13/K/1971 yaitu mengenai pembatasan usaha perusahaan asingdi sektor pariwisata. Dalam Keputusan Menteri ini, hanya beberapa sektor usaha pariwisata dibidang usaha angkutan pariwisata, objek-objek pariwisata, akomodasi atau perhotelan, pangan atau catering rekreasi dan usaha-usaha pariwisata pokok lainnya, yang dapat dilakukan oleh investasi asing. Hal ini bukan bertujuan untuk mendiskriminasi namun lebih kepada meminimalisir terjadinya dominasi perusahaan asing di Indonesia. ${ }^{8}$

“Undang-Undang tentang Pengesahan Agreement Establishing The World Trade Organization (WTO Agreement) atau Persetujuan Pendirian Organisasi Perdagangan Dunia yaitu Undang-Undang Nomor 7 tahun 1994 mengandung prinsip-prinsip Pelaksanaan dalam kegiatan Infestasi dalam bidang usaha pariwisata yang pada dasarnya tunduk pada ketentuan GATS yang masuk dalam sistem hukum Indonesia melalui Undang-Undang tersebut". "Hal tersebut terjadi akibat dari konsekuensi Negara Indonesia menjadi salah satu Negara yang menjadi anggota WTO". Dengan demikian ketentuan tersebut mensyaratkan bahwa setiap Negara anggota menpunyai hak penuh, berdasarkan jasa, namun kebijakan tersebut harus memperhatikan GATS. Adapun GATS ini memiliki prinsip-prinsip seperti berikut ; Perlakuan Khusus untuk Negara Berkembang, Kerjasama Negara Bukan Anggota, Most Favoured National NationTreatment, Transparansi, Kerentuan Domestik, Standar Monopoli, Hambatan, Pengecualian Umum, Akses Pasar.

Dalam hal mengenai perlakuan dalam bidang usaha sesungguhnya ketentuanketentuan mengenai pembatasan usaha bagi investasi asing yang berlawanan dengan Persetujuan GATS Artikel II jo XVII, dalam persetujuan tersebut menegaskan tidak boleh ada Negara Anggota WTO yang memberikan tindakan berbeda antara penyedia jasa dalam negeri dan penyedia jasa asing. Setiap Negara anggota haruslah mendapatkan perlakuan yang sama dengan kegiatan penanaman modal tanpa memisahkan status penanaman modal yang dilakukan baik sebagai PMA atau PMDN.

Pada praktek di Negara lain, juga terdapat beberapa perlakuan menyangkut pelarangan pihak asing memasuki bidang-bidang usaha tertentu dan Hak Guna Bangunan merupakan salah satu cara untuk mendukung penyelenggaraan investasi dalam bidang pariwisata. Pada umumnya, bidang-bidang usaha yang tertutup bagi

\footnotetext{
7 IGN Parikesit Widiatedja II, 2011, Kebijakan Liberalisasi Pariwisata, Konstruksi Konsep Ragam Masalah dan Alternative Solusi, Udayana University Press, Bali, hal. 102.

${ }^{8}$ Nyoman S. Pendit, 2003, Ilmu Pariwisata Sebuah Pengantar Perdana, Pradnya Paramitha, Jakarta, hal.13.
} 
kepemilikan asing adalah pertahanan, public utility, explorasi sumber alam. Larangan ini terdapat di Myanmar dana Jepang. Sementara, Srilanka, India dan Philipina memberlakukan larangan usaha di bidang perdagangan. ${ }^{9}$

Namun persetujuan GATS membenarkan perbedaan perlakuan tersebut. Ketentuan tentang perlakuan sama dalam Persetujuan GATS ruang lingkupnya terbatas pada dua hal, yakni hanya berlaku untuk investor jasa dan terbatass pada schedule of specific commitments yang diberikan negara-negara anggota. Oleh karena itu, negara tersebut masih bisa menerapkan suatu perbedaan perlakuan sepanjang perbedaan tersebut tidak membatasi akses perusahaan asing terhadap barang dan jasa yang ditujukan untuk mempengaruhi pembelian, penjualan atau distribusi barang dan jasa domestik.10

Berkaitan dengan ketidakpastian hukum yang terjadi ini, pada teori yang relevan untuk digunakan untuk mengurai permasalahan ini yaitu teori tentang jenjang norma (stufentheorie) yang dikemukakan oleh pakar hukum Hans Kelsen. "Yang mana dalam teori ini berpendapat bahwa sifat norma-norma hukum itu memiliki jenjang-jenjang dan berlapis-lapis yang tersusun dalam tata susunan hierarki, dumana suatu norma yang tinggi berlaku, dan berdasar, dan bersumber pada norma yang lebih tinggi lagi, demikian seterusnya sampai pada suatu norma yang tidak dapat ditelusuri lebih lanjut dan bersifat hipotesis dan fiktif yaitu Norma dasar atau Grundnorm". ${ }^{11}$

Pada intinya dengan berlakunya Undang-Undang Nomor 7 tahun 1994 tantang Persetujuan Pendirian Organisasi Perdagangan Dunia, investor yang berasal dari dalam negeri maupun investor asing memiliki hak yang sama dalam hal melakukan kegiatan investasi. Dengan demikian tidak menutup kemukian investor asing dapat mendominasi iklin investasi di Indonesia. Untuk mengsiasati hal tersebut salah satu tindakan yang dapat dilakukan misalnya dalam kegiatan investasi di bidang partiwisata. Dengan jalan pemilik tanah yang akan digunakan untuk investasi pariwisata hanya memberikan hak guna bangunan kepada pihak investor, sehinnga tidak kehilangan kepemilikan atas tanahnya dan dapat mencegah penggeseran penduduk asli digantikan dengan investor-investor luar yang nantinya akan berdampak pada memudarnya kebudayaan asli setempat.

\subsection{Penatagunaan Tanah untuk Kepentingan Pariwisata}

Sebagai langkah lain dari pemerintah untuk menjamin kesejahtaraan rakyat Indonesia, yaitu dengan jalan pemanfaatan tanah yang terlantar bagi rakyat yang membutuhkan dengan mengeluarkan regulasi berupa Peraturan Pemerintah Nomor 36 Tahun 1998 tentang Penertiban dan Perdayagunaan Tanah Terlantar. Yang dimaksud dengan tanah terlantar adalah tanah yang terbengkalai atau diabaikan oleh pemegang hak pengelolaan tanah, gpemegang hak atas tanah atau oleh mereka yang memperoleh

\footnotetext{
9 Toman Sony Tambunan dan Wilson R.G Tambunan, 2019, Hukum, Prenamedia Group, Jakarta, hal. 207.

10 Basuki Antariksa, 2016, Kebijakan Pembangunan Kepariwisataan (Pengembangan Kepariwisataan yang Berkelanjutan dan Perlindungan Kekayaan Intelektual, Intrans Publishing, Malang, hal. 102.

${ }^{11}$ Maria Farida, 2006, Ilmu Perundang-Undangan Dasar-Dasar Pembentukannya, Kanisus, Yogyakarta, hal. 25.
} 
dasar penguasaan tanah, tetapi belum memperoleh hak atas tanah sesuai dengan ketentuan peraturan perundang-uangan yang berlaku ${ }^{12}$

Regulasi terbaru yang berkaitan dengan tanah terlantar yaitu Peraturan Pemerintah Nomor 11 Tahun 2010 tentang Penertiban dan Pendayagunaan Tanah Terlantar, serta regulasi lainnya berupa Peraturan Kepala Badan Pertanahan Nasional RI Nomor 4 Tahun 2010 tentang Tata Cara Penertiban Tanah Terlantar ${ }^{13}$. Pada Peraturan Kepala Badan Pertanahan Nasional RI Nomor 4 Tahun 2010 tentang Tata Cara Penertiban Tanah Terlantar ini terkandung pemegang hak atas tanah, sehingga dengan sewenang-wenang menelantarkan tanahnya, yang pada dasarnya mempunyai sanksi ${ }^{14}$

Adanya tanah terlantasr ini sebenrnya dapat di lakukan penatagunaan tanah untuk memaksimalkan potensi yang ada sehinga dapat mewujudkan kesejahteraan rakyat Indonesia. Penataggunaan tanah sebenarnya telah diatur dalam Peraturan Pemerintah Nomor 16 Tahun 2004 tentang Penatagunaan Tanah. Dalam ketentuan ini yang dimaksud dengan penataan tanah adalah sama dengan pola pengelolaan tata guna tanah yang meliputi penguasaan, penggunaan dan pemanfaatan tanah yang berwujud konsolidasi pemanfaatan tanah melalui pengaturan kelembagaan yang terkait dengan pemanfatan tanah sebagai satu kesatuan sistem untuk kepentingan masyarakat secra adil. yang mana hal ini terkandung dalam Pasal 1Peraturan Pemerintah Nomor 16 Tahun 2004 tentang Penatagunaan Tanah.

Asas-asas dalam Penataangunaan tanah adalah keterpaduan, harus berdaya guna dan berhasil guna, selaras, serasi, seimbang, berkelanjutan, keterbukaan meliputi perlindungan hukum dan berkeadilan, sebagaimana terkandung dalam Pasal 2 Peraturan Pemerintah Nomo 16 Tahun 2004 tentang Penatagunaan Tanah. Dapat dijabarkan sebagai berikut :

a) keterpaduan

bahwa penatagunaan tanah dilakukan untuk mengharmonisasikan penguasaan, penggunaan dan pemanfaatan tanah.

b) berdayaguna

Yang dimaksud dengan berdayaguna dan berhasilguna adalah bahwa penatagunaan tanah harus dapat mewujudkan peningkatan nilai tanah yang sesuai dengan fungsi ruang

c) serasi, selaras dan seimbang

Yang dimaksud dengan serasi, selaras dan seimbang adalah bahwa penatagunaan tanah menjamin terwujudnya keserasian, keselarasan dan keseimbangan antara hak dan kewajiban masing-masing pemegang hak atas tanah atau kuasanya sehingga meminimalkan benturan kepentingan antar penggunaan atau pemanfaatan tanah

12 Supriyanto, Kriteria Tanah Terlantar Dalam Peraturan Perundangan Indonesia, Jurnal Dinamika Hukum, Vol 10 Nomor 1 Januari 2016, hal. 57, http://jurnal.untagsby.ac.id/index.php/dih/article/view/2235/1908 diakses pada tanggal 22 september 2019

${ }^{13}$ Ibid.hal. 54 .

${ }^{14}$ Arie Bestary, Analisis Yuridis Kelemahan Kriteria Tanah Terlantar Yang Berstatus Hak Milik, Vol 2 E-Journal Gloria Yuris Nomor 3 Tahun 2014, hal. http://jurnal.untan.ac.id/index.php/jmfh/article/view/5148 diakses pada tanggal 22 september 2019 
d) berkelanjutan

Yang dimaksud dengan berkelanjutan adalah bahwa penatagunaan tanah menjamin kelestarian fungsi tanah demi memperhatikan kepentingan antar generasi

e) keterbukaan

Yang dimaksud dengan keterbukaan adalah bahwa penatagunaan tanah dapat diketahui seluruh lapisan masyarakat.

f) persamaan, keadilan dan perlindungan hukum

Yang dimaksud dengan persamaan, keadilan dan perlindungan hukum adalah bahwa dalam penyelenggaraan penatagunaan tanah tidak mengakibatkan diskriminasi antar pemilik tanah sehingga ada perlindungan hukum dalam menggunakan dan memanfaatkan tanah.

Penatagunaan tanah juga diatur dalam Undang-Undang Pokok Agraria lebih khususnya lagi terdapat dalam Pasal 14, dimana dalam Pasal ini mengatur soal perencanaan persediaan, peruntukan dan penggunaan bumi, air dan ruang angkasa demi kesejahtaraan rakyat. "Mengingat akan corak perekonomian Negara dikemudian hari dimana industri dan pertambangan akan mempunyai peranan yang penting, maka disamping perencanaan untuk pertanian perlu diperhatikan, pula keperluan untuk industri dan pertambangan". Perencanaan itu tidak saja bermaksud menyediakan tanah untuk pertanian, peternakan, perikanan, industri dan pertambangan, tetapi juga ditujukan untuk memajukannya.

Lebih lanjut lagi Johara T. Jatadinata dalam bukunya yang berjudul Tata Guna Tanah Dalam Perencanaan Pedesaan Perkotaan \& Wilayah berpendapat bahwan Tataguna tanah atau dalam dalam bahasa lain desebut land use adalah pengaturan penggunan tanah. Tata yang dalam hal ini berarti pengaturan. Yangdibicarakan dalam tataguna tanah tidak hanya sebatas mengenai penggunaan permukaan bumi di daratan saja, tetapi juga meliputi pernggunaan permukiman bumi di lautan ${ }^{15}$.

Tujuan dari tata guna tanah harus diarahkan untuk dapat mencapai sebesar-besar kemakmuran rakyat. Usaha-usaha yang dilakukan untuk mencapai tujuan tersebut dapat dijabarkan sebagai berikut : "pertama, Mengusahakan agar tidak terjadi penggunaan tanah yang salah tempat; kedua, Maksudnya setiap kegiatan yang memerlukan tanah harus diperhatikan mengenai data kemampuan fisik tanah untuk mengetahui sesuai tidaknya kemampuan tanah tersebut dengan kegiatan yang akan dilaksanakan; ketiga, Mengusahakan agar tidak terjadi penggunaan tanah yang salah urus; keempat, Maksudnya setiap harus melaksanakan kewajibannya memelihara tanah yang dikuasainya. Hal ini untuk mencegah menurunnya kualitas sumber daya tanah yang akirnya akan timbul kerusakan tanah; kelima, Mengusahakan adanya penggendalian terhadap perkembangan kebutuhan masyarakat akan tanah, Pengendalian ini dilakukan untuk menghindari konflik kepentingan akibat penggunaan tanah; keenam, Mengusahakan agar terdapat jaminan kepastian hukum bagi hak-hak atas tanah warga masyarakat, ketujuh, Jaminan kepatian hukum penting untuk melindungi warga masyarakat yang tanahnya diambil untuk kepentingan proyek pembangunan'.

15 Johara T. Jayadinata, 2009,Tata Guna Tanah Dalam Perencanaan Pedesaan Perkotaan \& Wilayah, Bandung : ITB, , hal. 28. 
Berdasarkan ketentuan PP No. 16 Tahun 2004 tentang Penatagunaan Tanah tujuan dari penatagunaan tanah ialah pemanfaatan tanah sebagai satu kesatuan sistem untuk kepentingan masyarakat secara adil. Secara rinci penatagunaan tanah bertujuan untuk:

a. mengatur penguasaan, penggunaan dan pemanfaatan tanah bagi berbagai kebutuhan kegiatan pembangunan yang sesuai dengan RTRW;

b. mewujudkan penguasaan, penggunaan dan pemanfaatan tanah agar sesuai dengan arahan fungsi kawasan dalam RTRW;

c. mewujudkan tertib pertanahan yang meliputi penguasaan, penggunaan dan pemanfaatan tanah serta pengendalian pemanfaatan tanah;

d. menjamin kepastian hukum untuk memanfaatkan tanah bagi masyarakat yang mempunyai hubungan hukum dengan tanah sesuai dengan RTRW yang telah ditetapkan.

Kebijakan penatagunaan tanah diselenggarakan terhadap bidang-bidang tanah yang sudah ada haknya baik yang sudah atau belum terdaftar, tanah Negara, tanah ulayat masyarakat hukum adat sesuai dengan ketentuan peraturan perundangundangan yang berlaku. "Penggunaan dan pemanfaatan tanahnya harus sesuai dngan Rencana Tata Ruang Wilayah yang ditentukan berdasarkan pedoman, standar dan kriteria teknis yang ditetapkan oleh Pemerintah. Pedoman, standar dan kriteria teknis pelaksanaan kegiatan penatagunaan tanah diatur lebih lanjut oleh Pemerintah Kabupaten/Kota".

Dalam hal penyelenggaraan kegiatan kepariwisataan Pemerintah memiliki fungsi untuk menyediakan pengaturan dan melaksanakan pengawasan agar tercapainya tujuan untuk membangun penyelenggaraan kepariwisataan, pelestarian lingkungan serta peragaman obyek dan daya tarik wisata yang serasi dan selaras. Dalam Undang-Undang Kepariwisataan tepatnyaa pada hal menimbang point c dan point d Mengandung arti bahwa kepariwisataan merupakan bagian integral dari pembangunan nasional yang dilakukan secara sistematis, terencana, terpadu, berkelanjutan dan bertanggung jawab dengan tetap memberikan perlindungan terhadap nilai-nilai agama, budaya yang hidup dalam masyarakat, kelestarian dan mutu lingkungan hidup.

Pasal 4 point e dan f Undang-Undang Kepariwisataan menjabarkan lebih lanjut dengan menyatakan bahwa kepariwisataan bertujuan dalam melestarikan alam, lingkungan, dan sumber daya serta memajukan kebudayaan dapat disimpulkan bahwa Undang-Undang Kepariwisataan memberikan ruang terhadap perkembangan nilai-nilai budaya yang hidup dan berkembang di masyarakat, yang saat ini dikenal dengan nilai-nilai kearifan lokal. Selain itu dalam Undang-Undang Kepariwisataan ini nilai-nilai kearifan lokal memperoleh jaminan perlindungan secara hukum.

Pemberian penekanan pada pelestarian kekayaan alam, budaya dan lingkungan hidup sudah menjadi harga mati yang menjadi keunggulan komparatif kita. Dalam era globalisasi seperti sekarang ini kegiatan penyelenggaraan pariwisata mensyaratkan pengelolaan suatu produk jasa pariwisata yang profesional dan berkualitas unggul, serta memiliki daya pembeda dalam berkompetisi dengan produkproduk dari Negara kompetitor lainnya. 16

Pencapaian iklim investasi pariwisata yang kondusif secara berkelanjutan tidak terlepas daripada usaha untuk melakukan peningkatan koordinasi antar instansi baik di tingkat pusat maupun daerah serta upaya untuk memperoleh dukungan dari

${ }^{16}$ IGN Parikesit Widiatedja II, Op.Cit, hal. 111. 
pengusaha dan masyarakat. Pelibatan pemangku kepentingan kita akan dapat melihat apa tantangan, serta peluang harapan dari investasi pariwisata di masa yang akan datang. keikutsertaan mereka ini mampu kemudian melahirkan kebijakan yang akurat dan tepat sasaran sekaligus menciptakan peluang meningkatkan kualitas daya dukung pariwisata.

Munculnya keinginan untuk menjadikan kekayaan alam dan budaya sebagai hal ayng ditonjolkan yang bersifat komparatif, memiliki pengaruh positif dan menjadi penggerak baik secara langsung maupun tidak langsung pada upaya peningkatan pelestarian alam dan budaya itu sendiri.Hal ini tentunya memberikan kontribusi bagi pembangunan secara keseluruhan. Penyelenggaraan kegiatan pariwisata juga tidak terlepas dari keterlibatan masyarakat lokal secara intensif, fimana masyarakat lokal ini memiliki karakteristik budaya tersendiri yang melekat pada masyarakat tersebut, kemudian dikonversi menjadi sebuah daya tarik wisata yang menarik minat wisatawan untuk terus berkunjung.Seperti halnya dengan masyarakat di Bali yang memiliki Konsep Tri Hita Karana, konsep ini mengajarkan agar manusia memiliki keharmonisan dengan Tuhan, dengan manusia dan dengan lingkungan. Jika konsep ini kemudian diwujudkan dalam pembuatan kebijakan-kebijakan yang berorientasi pada pengembangan kegiatan pariwisata, maka laju pertumbuhan pelestarian alam dan budaya dapat dilakukan dengan sangat cepat.

Di dalam Undang-Undang Nomor 25 Tahun 2007 tentang Penanaman Modal khususnya dalam Pasal 30 menegaskan bahwa pemerintah daerah diminta untuk lebih diberdayakan baik dalam pengembangan potensi di setiap areah maupun dalam hal melakukan promosi yang berkaitan dengan kepariwisataan serta pelayanan penanaman modal.

Hal tersebut pula ditegaskan di dalam Undang-Undang Nomor 10 Tahun 2009 tentang Kepariwisataan, disebutkan bahwa pemerintah dan Pemerintah Daerah berkewajiban menyediakan informasi kepariwisataan, perlindungan hukum serta keamanan dan keselamatan kepada wisatawan, hal tersebut terkandung dalam Pasal 23 ayat $(1 \mathrm{a})$.

"Secara obyektif bahwa prospek pengembangan penanaman modal khususnya penanaman modal asing dalam bidang pariwisata sangatlah menjanjikan dan memberi peluang yang besar, dengan syarat pemerintah mampu membuat berbagai kebijakan yang dapat mendukung kegiatan pariwisata secara adil dan tanpa diskriminasi di dalamnya" ${ }^{17}$ Pengaturan mengenai kebijakan-kebijakan di bidang investasi pariwisata ini untuk memberikan jaminan kepastian hukum, perlindungan hukum dan rasa aman dalam berusaha bagi investor dalam kegiatan penanaman modal di Negara penerima modal. Selain itu diharapkan adanya pengaturan yang jelas dan tegas di tingkat daerah terkait penyelenggaraan investasi kepariwisataan mampu memberikan peluang bagi masyarakat untuk berkembang sehingga dampak yang terjadi pada bidang bisnis pariwisata ini dapat dirasakan secara menyeluruh oleh masyarakat lokal.

Dalam “Pasal 4 UU Penanaman modal telah diatur tentang kebijakan dasar penanaman modal yang menjadi acuan dan pedoman dalam pengembangan system penanaman modal di Indonesia baik penanaman modal asing, maupun modal dalam negeri". "Secara tegas disebutkan bahwa pemerintah menetapkan kebijakan dasar penanaan modal untuk mendorong terciptanya iklim usaha nasional yang kondusif

17 Aminuddin Ilmar, 2010, Hukum Penanaman Modal di Indonesia, Kuwais, Jakarta Timur, hal. 263-264. 
bagi penanaman modal untuk penguatan daya saing perekonomian nasional, dan untuk pengaturan daya saing perekonomian nasional dan mempercepat peningkatan penanaman modal 18 , Oleh karena itu, pemerintah membuat suatu kebijakan dengan memperhatikan kepentingan nasional yaitu memberikan perlakuan yang sama terhadap penanam modal dalam negeri maupun penanam modal asing dan semenjak proses pengurusan perizinan sampai dengan berakhirnya kegiatan penanaman modal usaha pemerintah menjamin kepastian hukum, usaha, keamanan usaha sejalan dengan peraturan perundang-undangan yang berlaku dan membuka peluang bagi perkembangan dan juga memberikan perlindungan kepada usaha mikro, kecil, menengah, koperasi". ${ }^{19}$

Dalam hal pembangunan kawasan pariwisata perlu kiranya dibangun suatu objek dan daya Tarik wisata serta prasarana dan sarana pendukung kegiatan pariwisata. tidak perlu adanya pengartian khusus dari kawasan pariwisata yang dalam hal ini meliki arti eksklusif yang bersifat tertutup. Kawasan Pariwisata harus merupakan kawasan yang sifatnya terbuka, guna bertujuan untukpengembangan suatu kawasan sebagai tujuan wisata.

Pengaturan yang melingkupi dari kegitan usaha kawasan pariwisata tercantum dalam Undang-Undang Nomor 10 Tahun 2009 tentang kepariwisataan tepatnya pada pasal 29. Yang termasuk kegiatan usaha kawasan pariwisata adalah :

a) Penyewaan laha yang mana dalam lahan tersebut telah dilengkapi dengan prasarana sebagai tempat myenyenggarakan pariwisata.

b) penyewaan fasilitas pendukung kegiatan periwisata lainnya.

c) penyediaan bangunan-bangunan yang diperuntikkan untuk menunjang kegiatan usaha pariwisata yang berada di dalam kawasan pariwisata.

d) badan usaha kawasan pariwisata juga menyelenggarakan sendiri usaha pariwisata lain dalam kawasan pariwisata yang bersangkutan.

Dalam Pasal 97 UU Kepariwisataan mengatur mengenai Kewajiban badan usaha kawasan pariwisata. "Pada intinya Badan Usaha kawasan pariwisata berkewajiban untuk menyediakan dan membangun fasilitas dan sarana prasarana lain yang termasuk didalamnya melakukan pematangan lahan yang akan digunakan sebagai tenpat kegiatan usaha pariwisata; Membangun dan menyediakan sarana, prasarana dan fasilitas lain, termasuk melakukan pematangan lahan yang akan digunakan untuk kegiatan usaha pariwisata; Mengendalikan kegiatan pembangunan dan pengelolaan sarana dan prasarana dengan memperhatikan kepentingan kelestarian lingkungan; Mengurus perizinan yang diperlukan bagi pihak lain yang akan memanfaatkan kawasan pariwisata untuk menyelenggarakan kegiatan pariwisata untuk menyelenggarakan kegiatan usaha pariwisata; Memperhatikan kebijaksanaan pengembangan wilayah yang berlaku, dan memberikan kesempatan kepada masyarakat di sekitarnya untuk berperan serta dalam kegiatan usaha pariwisata di dalam kawasan pariwisata; Pelaksanaan usaha kawasan pariwisata dilakukan harus sesuai dengan Rencana Tata Ruang Wilayah dan Rencana Induk

${ }^{18}$ Tindangen, G. Y. (2016). Perlindungan Hukum Terhadap Investor Menurut Undang-Undang Nomor 25 Tahun 2007 tentang Penanaman Modal. Lex Administratum, 4(2).

hal. 18

${ }^{19}$ Ibid. 
Pengembangan Pariwisata Nasional serta Rencana Induk Pengembangan Pariwisata Daerah $20^{\prime \prime}$.

Ketentuan ini menegaskan pemanfaatan tanah untuk kepentingan pariwisata dapat dilakukan melalui bergai bentuk kerjasama antara investor dengan pemilik lahan-lahan strategis dengan pemberian Hak guna Bangunan sebagai alas haknya.

\section{Kesimpulan}

Prinsip-prinsip penyelenggaraan investasi dengan menggunakan hak guna bangunan sebagai alas haknya dapat membantu pengembangan pariwisata karena pemegang hak milik atas tanah tidak kehilangan kepemilikan atas tanahnya, dan juga dalam melakukan investadi di bidang pariwisata ijin merupakan hal yang paling esensi untuk dimiliki. Penataan Pembangunan pariwisata berkelanjutan merupakan pembangunan yang berdimensi ekonomi, social budaya, dan lingkungan hidup sehingga memiliki keadilan tidak hanya untuk generasi yang akan datang. Dalam konstruksi ini, pariwisata harus dipandang sebagai suatu sistem yang meliputi beragam komponen yang saling berinteraksi dan saling mempengaruhi. Oleh karena itu, dibutuhkan suatu sinergi kebijakan yang mengatur penyelenggaraan pariwisata dengan pendekatan multisektor dan multidisiplin integrasi pelayanan, dan sinergisitas pemerintah dan masyarakat dalam pemanfaatan tanah dengan Hak Guna Bangunan untuk kepentingan pariwisata.

\section{Daftar Pustaka / Daftar Referensi}

\section{Buku-Buku}

Fuady, Munir, 2013, Teori-Teori Besar (Grand Theory) Dalam Hukum, Cetakan Pertama, Kencana, Jakarta.

Ilmar, Aminuddin, 2010, Hukum Penanaman Modal di Indonesia, Kencana, Jakarta.

Marzuki, Peter Mahmud, 2008, Pengantar Ilmu Hukum, Kencana, Jakarta.

Morris L. Cohen \& Kent C. Olson, 2000, Legal Research, In A Nutsell, West Group, ST. Paul, Minn, Printed in The United States of America, Page 1.

Mulyadi, Kartini dan Gunawan Widjaja, 2004, Hak-Hak atas Tanah, Kencana Predana Media Group, Jakarta.

Pendit, Nyoman. S, 2003, Ilmu Pariwisata Sebuah Pengantar Perdana,Pradnya Paramitha, Jakarta.

Rasjidi, H. Lidi dan Liza Sonia Rasjidi, S.H.,M.H, 2016, Dasar-Dasar Filsafat dan Teori Hukum, PT. Citra Aditya Bakti, Bandung.

20 Violetta Simatupang, 2009, Pengaturan Hukum Kepariwisataan Indonesia, P.T. Alumni, Bandung, hal. 200-201. 
Salim HS dan Budi Sutrisno, 2014, Hukum Investasi di Indonesia, Cetakan Ke-4, PT. Raja Grafindo Persada, Jakarta.

Santoso, Urip, 2012, Hukum Agraria : Kajian Komperhensif, Kencana Prenada Media Group, Jakarta.

Supanca, Ida Bagus Rahmadi, 2006, Kerangka Hukum Dan Kebijakan Investasi Langsung di Indonesia, Ghalia Indonesia, Bogor.

Wyasa Putra, Ida Bagus, dkk, 2010, Hukum Bisnis Pariwisata, Refika Aditama, Bandung.

Widiatedja, IGN. Parikesit, 2011, Kebijakan Liberalisasi Pariwisata, Konstruksi Konsep Ragam Masalah dan Alternative Solusi, Udayana University Press, Bali.

\section{Peraturan Perundang-Undangan}

Undang-Undang tentang Penanaman Modal Nomor 25 Tahun 2007 (Lembaran Negara Republik Indonesia Tahun 2007 Nomor 67).

Undang-Undang Nomor 10 Tahun 2009 Tentang Kepariwisataan (Tambahan Lembaran Negara Republik Indonesia Nomor 4966), diundangkan di Jakarta, pada tanggal 16 Januari 2009.

Undang-Undang Nomor 7 Tahun 1994 yaitu Undang-Undang tentang Pengesahan Agreement Establishing The World Trade Organization (WTO Agreement) atau Persetujuan Pendirian Organisasi Perdagangan Dunia.

Peraturan Daerah Provinsi Bali Nomor 2 Tahun 2012 Tentang Kepariwisataan Budaya Bali (Lembaran Daerah Provinsi Bali Tahun 2012 Nomor 2), diundangkan di Denpasar, pada tanggal 15 Maret 2012.

\section{Artikel/Jurnal}

Muschilisin Riadi, 2017, Pengertian, Fungsi dan Dimensi Kearifan Lokal, https:// www.kajianpustaka.com/2017/09/pengertian-fungsi-dimensikearifan-lokal.html, diakses Kamis, 8 Maret 2018.

Grandnaldo Yohanes Tindangen, Perlindungan Hukum Terhadap Investor Menurut Undang-Undang Nomor 25 Tahun 2007 tentang Penanaman Modal, Jurnal Lex Administratum, Volume 4 Nomor 2 Tahun 2016, Universitas Sam Ratulangi, hal. 18, https://ejournal.unsrat.ac.id/index.php/administratum/ article/view/11291/10880 diakses 7 april 2018.

Supriyanto, Kriteria Tanah Terlantar Dalam Peraturan Perundangan Indonesia, Jurnal Dinamika Hukum, Vol 10 Nomor 1 Januari 2016, hal. 54, http://jurnal.untagsby.ac.id/index.php/dih/article/view/2235/1908 diakses pada tanggal 22 september 2019 
Arie Bestary, Analisis Yuridis Kelemahan Kriteria Tanah Terlantar Yang Berstatus Hak Milik, Vol 2,E-Journal Gloria Yuris Nomor 3 Tahun 2014, hal. http://jurnal.untan.ac.id/index.php/jmfh/article/view/5148 diakses pada tanggal 22 september 2019

Nyoman Dharmantra, 2018, "Pariwisata Budaya atau Komersialisasi Budaya" artikel Koran Bali Post, Selasa, 13 Februari 2018. 